\title{
PRACTICES OF STRATEGY COMMITTEES OF SUPERVISORY BOARDS
}

\author{
Izabela Koładkiewicz*, Małgorzata Kuczara**, Michał Zdziarski***
}

\begin{abstract}
Background. This article presents the very first research on strategy committees in the context of Polish supervisory boards. Consequently, it is also the first study on strategy committees of supervisory boards conducted in the European, two-tier system of corporate governance.
\end{abstract}

Research aims. The article aims to explore practices of strategy committees in supervisory boards, including factors conditioning the formation of a committee, criteria for membership selection, as well as functions, tasks, and operations that are undertaken by the committees.

Methodology. The research presented in this paper was conducted via the method of interviews with 10 board members selected according to the stratified sampling, having both vast experience in the function of a board member at several companies, and experience of participation in a strategy committee.

Key findings. Their narration suggests that a strategy committee serves as a structural solution supporting the engagement of the board in the company's strategy process. A strategy committee plays an advisory role for the board, which decides on the final strategy. An opportunity to focus attention on key factors influencing strategy formulation is perceived as a key dimension of a committee's works. A committee may be permanent or formed ad hoc if a strategic renewal is needed. Critical factors that seem to increase the likelihood of committee formation are the size and complexity of a company.

Key words: strategy committee, supervisory board, strategy, corporate governance, strategy as practice

Acknowledgements: The authors thank Prof. Maria Aluchna and Michał Rogatko for their contribution to the research. They also thank Board Center and Spencer Stuart Poland for financial support.

\footnotetext{
* Kozminski University. E-mail: izabela@kozminski.edu.pl

** Faculty of Management, University of Warsaw. E-mail: mkuczara@wz.uw.edu.pl

**** Faculty of Management, University of Warsaw. E-mail: mzdziarski@wz.uw.edu.pl
} 


\section{INTRODUCTION}

The main objective of the article is to explore the practices of strategy committees in supervisory boards, including factors conditioning the formation of a committee, tasks, and operations that are undertaken by committees.

A strategy committee is a relatively rare organisational solution supporting the engagement of supervisory boards in the process of formulation, implementation, and supervision of a company's strategy. It is much less popular than other types of committees, such as audit, remuneration, nomination, and risk committees, which may be found in public corporations. The practices and effects of functioning of the aforementioned committees have recently been the focus of a growing volume of research in the areas of finance, management, and corporate governance (Kaczmarek, \& Nyuur, 2016). So far, the results of research on the effectiveness of supervisory boards at Polish companies indicate that it is largely affected by the committees formed within them (Koładkiewicz, 2014).

The popularisation of the division of work within committees is an effect of attempts to institutionally reform the rules of corporate supervision in order to mitigate the risk of value loss at public companies and the ensuing systemic risk. Recommendations regarding the appointment of audit, nomination, risk, and remuneration committees as concerns the practical functioning of boards of directors/supervisory boards may be found in both legal regulations and corporate governance codes of good practices in numerous countries all over the world (Spira, \& Bender, 2004; Kaczmarek, \& Nyuur, 2016). It should be noted that this does not apply to strategy committees. One interesting exception to this pattern is the Russian collection of good practices, which does bring up the strategy planning committee. The task of this committee is to "facilitate the increase of the company's business effectiveness in the long-term" (Corporate Governance Code Russia, 2014, p. 9), and its role consists in holding preliminary discussions on key strategic issues, and in presenting recommendations to the board. A strategy planning committee should play a significant role in determining the strategic goals of a company and the priority areas of operations, dividend payouts, evaluation of long-term productiveness and in providing advice on issues of company development policy, based 
on the market trends and performance of both the company and its competition (Corporate Governance Code Russia, 2014).

Discussion on the reforms of corporate governance principles today revolves on many capital markets around the necessity of mitigating risk, of activating boards of directors/supervisory boards and on increasing their influence on the strategy process (Casal, 2014). Thus, it seems that we may anticipate a growing popularity of strategy committees as an organisational form that favours a greater effectiveness of the board's influence on company decisions of key significance for the long-term company growth. It is also likely that the number of strategy committees may quickly increase if future corporate governance codes of good practices recommend this organisational form.

At the same time, the existing practices of strategy committees have not been thoroughly explored as of yet. A query of literature of the subject reveals that the issue of strategy committees has only been taken up in two scholarly articles over the past 30 years. The first article presents research results regarding strategy committees based on archive annual reports of American companies, where out of 753 researched boards of directors, only 15 had strategy committees. At the time, this solution was regarded as an innovation in the organisation of the board's work (Harrison, 1987). The second research, also conducted in the United States, indicates a growing popularity of strategy committees - they have been identified in 40 boards of directors out of the 485 researched (Klein, 1998). According to the best knowledge of the research team, strategy committees have never been researched in the continental, two-tier corporate governance system, and no research of this structure has been conducted outside of the United States. No articles providing guidelines to boards on when it is recommendable to appoint a strategy committee have been found, nor any that would furnish members of existing committees with a code of good practices. These premises indicate a literature gap, which justifies the adoption of an exploratory research objective, as well as the application of qualitative methods of analysis to investigate an important organisational phenomenon. For the purposes of this article, the objective of which is to explore the practices of strategy committees, the following research questions have been formulated:

1. What factors weigh in on the appointment of a strategy committee in a supervisory board? 
2. What functions and tasks are performed by a strategy committee?

3. What is the operating form of a strategy committee?

In order to answer these three questions, the researchers took a look into the "black box" of corporate governance in the process of qualitative research conducted under a larger project, the purpose of which was to present the practices of supervisory boards at Polish public companies. The article presents research results concerning the functioning of strategy committees in Polish supervisory boards. The first part is devoted to the issue of research on supervisory board committees. The next part presents the research project and a characterisation of interviewees, and is followed by the research results. The closing part is a summary, providing conclusions, limitations, and proposals for further directions of research on strategy committees.

\section{SUPERVISORY BOARD COMMITTEES - AN OUTLINE}

The increasing complexity of managing a modern company translates into a growing complexity of tasks faced by boards of directors/ supervisory boards. One of the responses to these challenges is the introduction of division of work in the boards by way of forming committees within them. The creation of this type of structures is a consequence of having realised "the diverse and complex nature of tasks faced by a contemporary board" (Dobija et al., 2011, p. 28). Their job is to become engaged in those areas of the board's activities which may become a potential source of conflicts of interest between the company's key stakeholders present in the authority structures. Research on the effectiveness of supervisory boards, conducted in Poland, points to the existence of committees as one of its determinants, besides a diverse composition of the board, ensuring variety of skills, independence, inquisitiveness of its members, as well as their capacity to obtain information. Committees improve the effectiveness of boards principally by structuring their work (Koładkiewicz, 2014).

Appointment and functioning of committees in boards has been institutionalised in the corporate governance codes of good practice which work according to the principle of "comply or explain". This process has been initiated by reforms of corporate governance introduced in Great Britain in the 1990s. The recommendations to appoint special audit, remuneration and nomination committees of the boards constituted 
a key element of the drafted documents of corporate governance good practices (Cadbury, 1992). Since then, we have been observing a growing popularity of similar recommendations also in other countries, as well as an increased number of board committees as a very important form of organising work of the board. The phenomenon of board committees has not eluded the scholars, who have undertaken research on them with great interest. Between 1988 and 2011, we had seen an exponential growth of the number of articles regarding committees of boards of directors/supervisory boards, published by researchers in the fields of management, finance, and accounting (Kaczmarek, \& Nyuur, 2016).

Research concerning board committees focuses mainly on those with oversight functions, the task of which is to limit the sources of conflicts of interests identified by the agency theory. They include audit, remuneration and nomination committees (Kaczmarek, \& Nyuur, 2016). The role of the first one is primarily to monitor processes of financial reporting, effectiveness of internal systems, internal audits and risk management, external audits and ensuring the independence of expert auditors. These committees limit the problem of agency by reducing the information asymmetry between people who have direct access to information owing to their handling of company's affairs and its external stakeholders. The key objective of an audit committee is to ensure that company's shareholders have complete and reliable financial information. Remuneration committees, on the other hand, allow companies to create and monitor motivational systems for higher management, which is to ensure alignment of the goals of management and shareholders (Klein, 1998). Lastly, nomination committees provide boards with recommendations regarding the appointment of new higher management officers, with account for the company needs (Dobija et al., 2011).

The type of committee most frequently encountered in Polish supervisory boards is the audit committee. In 2015, they functioned in the boards of 191 companies listed on the Warsaw Stock Exchange. The second most popular committee was the remuneration committee, found in 83 boards. Strategy committees functioned in the boards of $4 \%$ of listed companies, of which $35 \%$ were listed on the WIG20 index (PWC, 2016, p. 25).

The popularity of the audit committee stems primarily from its obligatory nature, which follows from the Act on statutory auditors of May 11, 2017 (the first Act was implemented in May 7, 2009). Not without significance for the number of different types of committees 
seems to be the fact that supervisory boards in Polish companies focus on the oversight and control functions, while attaching much less importance to advisory functions (Jeżak, \& Bohdanowicz, 2005). Of significant influence on the popularity of certain committees are also recommendations provided in the document entitled: "Good Practices of Companies Listed on the Stock Exchange 2016", which cites Annex 1 to the European Commission Recommendation dated February 15, 2005. This annex addresses three types of committees: audit, nomination, and remuneration. The European Commission Recommendation does not oblige boards to appoint such committees, but in the event of their absence, it encourages explanation of how the board performs tasks that should be within the competences of the audit and remuneration committees. Moreover, the European Commission Recommendation states that boards should not only perform self-evaluation as the entire body, but also that it should submit reports on the works of individual committees. The document underscores that a board is a collegiate body, and as such, it is collectively accountable for the performance of its duties (European Commission, 2005).

\section{STRATEGY COMMITTEE}

The research team has completed a query of global literature of the subject in the Scopus and Web of Science databases, with the use of the following keywords: strategy committee, strategic committee, long range planning committee, long-term investment committee, and strategic development committee, narrowing down its subject areas to: business, management, accounting, economics, econometrics, finance, and social sciences. The results of the analysis as at March 16, 2017 allow for the conclusion that the subject of strategy committees has not been explored by researchers, with the exception of the aforementioned two articles.

Thirty years ago, the subject of strategy committees was introduced in literature of management sciences based on the analysis of 15 annual reports of large American enterprises, in which this then new form of the board's work was identified (Harrison, 1987). Harrison emphasises that the number of strategy committees could in reality be larger, as companies do not always report on this type of structure, given that they are not formally obliged to do so. According to this author, the low popularity of strategy committees stems from the 
moderate engagement of boards in the processes connected with strategy. The results of his research reveal the existence of two main types of committees in boards of directors. The first of two are committees the basic roles of which are to support the operational activities and to provide advice in making key decisions. Committees of the second type perform a monitoring function and protect the rights of shareholders. They include audit, remuneration, and nomination committees. The basic task of this type of structure is to review the situation within a company in an objective, reliable, and independent manner, as well as to oversee compliance with the law and ethics. In the opinion of this author, a strategy committee cannot be unambiguously placed in either of the two aforementioned categories. This is due to the fact that it may engage in both processes connected with laying down a strategy and in supervising its performance. He also argues that all companies, both large and diverse and small, may draw benefits from having a strategy committee. In the first case, companies may see such benefits in highrisk moments, sudden changes in the business environment, when entering global markets or when hiring a new CEO. In small companies, which cannot afford the services of external consultants, members of the strategy committee may be the CEO's sole support in strategic issues. A strategy committee, especially one made up of independent members, may also be a source of an objective perspective in companies with a stable situation and a high level of routine, or in those which have had the same CEO for many years. The author emphasises that the entire board may focus on strategy, yet the main advantage of having a specialised committee is that its meetings will be devoted exclusively to strategy. Harrison points out two issues which require additional attention and answers, that is whether strategy committees should engage in formulating strategy or only supervise it, and what their responsibility should be (Harrison, 1987).

The second article was published in 1998, also based on research with a focus on American companies (Klein, 1998). Klein underscores in it that despite the absence of regulations and guidelines for strategy committees, they were present in 40 boards of directors, out of 485 researched companies. They reviewed and approved long-term projects and investment strategies. According to the author, "boards need specialized information on company activities, provided by experts, in order to evaluate and approve its long-term strategies" (Klein, 1998, p. 278). However, obtaining this knowledge requires time and a thorough 
understanding of company's affairs, which are two significant resources held by executive directors. Owing to information asymmetry, these resources are often unavailable to non-executive directors. Information asymmetry may explain the considerable representation of executive directors in strategy committees. It is also in line with the premises formulated based on the agency theory by Fama and Jensen (1983), according to which boards are more willing to appoint executive directors to committees that affect financial decisions and long-term investment strategies.

\section{RESEARCH DESIGN AND CHARACTERISATION OF INTERVIEWEES}

The existing literature on the issue of board committees is dominated by research focusing on American companies, conducted with the quantitative method and invoking the agency theory as the starting point of the research (Kaczmarek, \& Nyuur, 2016). The presented research diverges from the mainstream approach in three aspects:

1. It adopts the research perspective of strategy as a practice, without any a priori assumptions regarding theoretical mechanisms explaining the functioning of strategy committees.

2. The conducted research is of qualitative character, and it has been completed with the use of the interview technique. Interviews were partially structured, conducted with a group of interviewees selected according to the nonprobability sampling method, who have experience as both members of strategy committees and vast exposure to practices at numerous supervisory boards.

3. The research was completed in Poland, where the two-tier corporate governance system is in effect, sometimes referred to as 'continental', and which is also present in the legislation of many European countries (e.g. Germany or Austria).

In order to explore the practices of functioning of strategy committees (factors conditioning formation of a committee and "its" operations), thus broadening the existing knowledge on the engagement of supervisory board members in strategy, 10 experienced members of supervisory boards, who have participated in strategy committees were interviewed. The research formed part of a larger project the objective of which was to understand whether and how supervisory 
boards participate in the creation of company value and in processes of strategic significance. The selected interviewees were members of supervisory boards at companies listed on the Warsaw Stock Exchange in December 2015, and they were chosen according to the nonprobability sampling method. In total, 21 members of supervisory boards were interviewed, out of whom 10 had practice regarding the functioning of board strategy committees.

The applied technique of an interview is currently employed as the basic technique of data collection, which allows researchers to obtain information not only about individuals, but also about groups and organisations (Frey, \& Fontana, 2009, p. 86). Nevertheless, the responses obtained in the interviews should not be treated as "true or false reports on reality", but rather as "reflections of moral perspectives and forms" (Silverman, 2007, p. 139).

Interviews with key players co-shaping important practices of functioning of financial markets allow researchers to reach knowledge which is difficult, if not impossible, to arrive at in quantitative research (Pyfel, 2015).

Out of 3,138 members of supervisory boards of companies listed on the Warsaw Stock Exchange in December 2015, 134 respondents were selected, active in more than 3 boards. As indicated by research, appointment to boards of various organisations positively influences the strategic perspective and may be a basis of specialised expert knowledge of board members, as membership in each subsequent board increases the likelihood of exposure to experiences connected with key processes in enterprises, such as selection of the CEO, restructuring, or foreign expansion (Carpenter, \& Westphal, 2011). The purpose of our research is to present practices of functioning of strategy committees, which is why we intentionally selected members with a vast exposure to many supervisory boards and experience of membership in this committee. Ultimately, the article discusses the research conducted on 10 members of supervisory boards, who have been members of strategy committees. Members of the researched group frequently participated in the works of other committees 9 were involved with audit committees, 7 were members of nomination or remuneration committees, and 3 of risk committees. Seven have experience in company management and have held the function of CEOs. A substantial number of the respondents were members of supervisory boards who hold academic titles of at least a Ph.D.; only 
one respondent held an MBA. The article also cites statements made by interviewees, whom we have marked with the symbol $R$ followed by a unique ordinal number from 1 to 21 .

Table 1. Characterization of interviewees

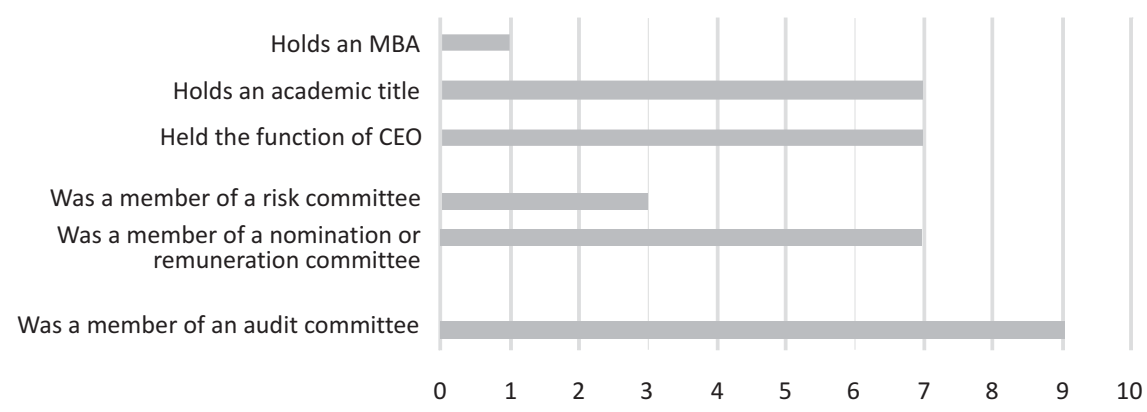

Source: own research of authors based on information published on corporate webpages of companies to whose structures the respondents were appointed.

In order to obtain knowledge regarding the practice of functioning of strategy committees, partially structured interviews were designed. The choice of qualitative methods, and especially of the interview technique, allows to create new knowledge, as well as to gain insight into the practices, experience, and opinions of the respondents (Kvale, 2011). In order to ensure the highest quality of the research, at the stage of formulating the research problem and interviews, we have applied researcher triangulation. Five scholars from three different universities have participated in this process. The interview structure has been also tested by three professionals with experience as members of supervisory boards. The interviews, conducted between March and June 2016, lasted 45 to 90 minutes, they were recorded, transcribed by an external company and subsequently encoded by two team members acting independently. Owing to the confidential nature of information regarding strategy and other corporate matters, we have ensured interviewees" anonymity.

The qualitative character of our study and the limited sample of only 10 committee members requires acknowledging that any general statements that we posit based on our study are based only on limited observations we were able to discover based on observations and experiences of our respondents. In presenting the results we have closely followed Michael G. Pratt's (2009) recommendation to use "power quotes" that bear important meaning for issues under investigation. 


\section{STRATEGY COMMITTEE - THE PERSPECTIVE OF THE INTERVIEWED BOARD MEMBERS}

Even though, in the opinion of one of the interviewed board members, the strategy committee is a basic board institution to work on strategy and in its overall practice "(...) they may be the most interesting part of any board" [R20], we still do not know much about it. One of the reasons for this is the fact that they are not very frequent in Polish supervisory boards. The appointment of a strategy committee is a good practice, which a supervisory board may apply or not. The experience of the respondents indicates that one of the determinants of forming a strategy committee in a board is the board's size. The larger the board, the more likely it is to be divided into smaller task groups, that is committees, which focus on the completion of tasks within a given area of company's functioning. Another observed factor that favours the appointment of a strategy committee is the size of the company itself. This observation is confirmed by, among others, comparison of the percentage of strategy committees in the boards of WIG20 and WIG40 companies. There were many more in WIG20 company boards (35\%) than in the boards of WIG40 companies (13\%) (PWC, 2015, p. 36). As attested to by the experiences of interviewed board members, another important stimulus for the appointment of a strategy committee is the need for it. Such experience was shared by respondent [R4], whose "(...) supervisory board arrived at the conclusion that there is some problem with the company's strategy and that it needs looking into (...) in a more hands-on way, which could also help the management, and for this purpose the committee was appointed". A similar experience was declared by respondent [R8], whose board appointed a strategy committee “(...) to review the strategy", and once this task was completed, the committee was dissolved. Interviewee [R8] expressed the opinion that there is no need for a standing strategy committee, justifying it as follows: "strategy is too important to leave it to the strategy committee".

The observed practice of appointing strategy committees in response to emerging needs may also explain its scarce presence in the boards of companies listed on the Stock Exchange, researched by PWC (2015). Where a committee is formed with the objective of solving a problem, and is subsequently dissolved, it may be treated as internal board 
activity and information on its functioning may not be available outside of the board or the company.

Regardless of whether a committee is a standing structure within the board, or if it is formed ad hoc, one important issue is the identification of criteria determining the selection of its members. The analysis of experience of interviewed board members indicates a fairly diverse set of criteria. It entails both expertise-related issues and situational ones. The fundamental expertise-related criteria include the board members' experience and competences. Nevertheless, the criteria for their evaluation may vary. The respondents have pointed out, among others, the usefulness of experience regarding:

- strategy formation [R11],

- management [R13],

- industry proficiency [R13], [R20].

The interviewees also noted the importance of more specialised, expert knowledge [R20] and [R21]. They have also underscored the ability to think [R14], as the strategy committee has the nature of "an expertise-based body, whose objective was to intensify the thinking process and strategic steps in the company" [R4].

The experience of the interviewed board members reveal that, besides the aforementioned expertise-related factors, of key significance were also the interest and willingness of board members to participate in the strategy committee's works [R4], [R14], [R15], and [R17]. Sometimes, the decisive circumstance is to "keep busy" those board members who are not part of any other committee [R13]. In summary, it may be concluded that the practice of appointing strategy committees shows two potential scenarios for their forming: delegation or invitation from the chairman of the supervisory board, whereas the criterion of selection are the competences of a given board member [R8], or coming forward as a volunteer. One important criterion is also the willingness to sacrifice one's time to participate in the committee's work.

In identifying the functions of the strategy committees, interviewed board members pointed out the strengthening of the advisory and supervisory, or just the advisory function of the board. According to interviewee [R17], this follows from the fact that a strategy committee "allows a selected group of people, along with internal and sometimes external experts, to delve deeper into certain aspects. (...) and to go over strategy much more thoroughly than the board which then approves it”. 
Others yet attributed the function of a reviewer to the strategy committee. The experiences of interviewee [R15] confirm the usefulness of this function of the strategy committee. In his career as CEO of a large company, he has collaborated with a strategy committee, along with the management board. In summarising this experience, he stated, among others: “(...) we of course were able to understand, that if the [strategy] committee had a strong opinion on a certain issue, we shouldn't force some ideas. We only had them in mind when presenting the final strategy [to the board]".

Another function attributed to the strategy committee had to do with its inspiring role, which consists in "(....) providing what you may call an impulse to drive and facilitate the management's focus on strategic issues, on identifying problems and seeking solutions to them" [R4].

As regards the supervisory board itself, the strategy committee fulfils the role of a body that solely recommends potential solutions. The choice of these solutions, however, lies with the board. The practice of functioning of the strategy committees as experienced by the interviewed board members shows that this committee:

- $\quad$ “(..) analyses a strategy at a deeper level, sometimes even over a number of meetings, and only once everything is cleared up, also between the committee and the management board, the given item goes to the board's agenda, where the committee (...) presents a sort of a preliminary opinion of its members and, we may say, deliberates on the first possible doubts" [R13];

- “(...) it would work out a preliminary version of an opinion or a recommendation and then it would be discussed at the supervisory board meetings" [R11];

- “(...) it is what you may call a real body usually appointed for ongoing collaboration with the management board; the supervisory board should and may exert an influence on the shape of the company's strategy, and it seems that if a consensus in this respect is reached between the management board and the supervisory board, then we have an optimum situation" [R15].

The characterisation that emerges from these experiences indicates that the key benefits following from a strategy committee are the ability of its members to delve into a given analysed issue and to work out preliminary proposals regarding strategy, which then should be discussed by the entire supervisory board. As an effect, as pointed out 
by interviewee [R4], “(...) the role of the supervisory board was no longer limited to presenting opinions on strategic documents already drafted by the management, or to just approving them". Owing to the work of the strategy committee, the supervisory board has an opportunity to influence the key elements of the strategy.

One interesting dimension of the strategy committee's work may also be the innovative ideas for the future discussed at its meetings, which are not as of yet perceived as part of strategy, but may afford potential strategic options. According to interviewee [R17], a strategy committee is a good solution for discussing this type of options.

As regards the method of functioning of the strategy committee, the experience of the interviewed board members reveals that its meetings are not attended exclusively by committee members; frequently, the entire board is invited to participate. Such were the experiences shared by, among others, respondent [R20], who said: “(...) Strategy committee members attend obligatorily. Other [board members] usually come, if invited".

Cooperation with the management board is another important dimension of the strategy committee's work. It certainly goes without saying that the quality of this cooperation translates into the final effect in the form of strategy proposals that find their way to the meetings of the entire board. In the event of the strategy committee headed by interviewee [R4], it worked "(...) in the form of brainstorms and strategic workshops". At this point, it is worth mentioning that this committee was not one of the standing committees of the supervisory board; it had been appointed with the purpose of supporting the management board in seeking strategic options adequate to the company needs. Thus, the mode of its work was determined by the management's progress in this scope. Therefore, its meetings were held when "(...) there was something to discuss, brought forward by either the committee or the management board. So it was not governed by any formal schedule, but rather by ongoing needs". In total, it would meet a few times a year [R4].

In those boards that had standing strategy committees, the manner of their operation was more formalised. For example, in the supervisory board of interviewee [R20], the meetings took place twice a year. The analysis of experiences of the interviewed board members shows that if a strategy committee is a standing one, the pattern of its work is governed by the committee's regulations. In such cases, it convenes 
a number of times every year - once, twice, three times, or once every quarter. The situation changes, however, when works on a strategy commence. At this point, the frequency of committee meetings significantly increases (e.g. [R11], [R14]). A similarly intense work rhythm of a strategy committee may be observed when it is appointed for the purposes of completing a specific task (e.g. to review the strategy). For example, the experience of interviewee [R8] shows that 'his' strategy committee, appointed to update the strategy, would meet with the management board every two weeks over a period of three consecutive months.

Asked to comment on the usefulness of strategy committees to the board, the interviewees rather unanimously claimed that they are beneficial. Nevertheless, their opinions varied as to the desired nature of this structure, whether it should be a standing body of the board, or one appointed on an as-needed basis, for example when there emerges the sensation "(...) that the company is facing certain strategic challenges that need be addressed, if the existing strategy" starts to raise doubts [R4]. Interviewee [R9], on the other hand, stated that “(...) strategy formation is also a fairly continuous process, for example, it needs to be refreshed every year, at which point the value of a strategy committee is probably greater".

Among the collected opinions, there were also some voices that in the event of small boards of 5 members, the entire board should be involved in strategic processes (e.g. [R9]). However, regardless of whether the strategy committee is a standing or an ad hoc body, the tasks handled by it remain the same and entail creative discussion over the preparation or updating of a strategy. The practice of the interviewed board members indicates that more often the committees cooperate with the management board in the updating of the strategy.

\section{DISCUSSION}

The gathered experiences regarding the functioning of strategy committees in supervisory boards enable the determination of their key features and tasks. It must however be emphasised that the qualitative character of this research allows only for drawing conclusions regarding the practice of the participating interviewees and cannot be extrapolated onto the entire population. Despite these limitations, 
it may be assumed that the obtained research results expand our knowledge of this institution of the supervisory boards and enable the evaluation of its usefulness. Further, conducted research is one of the first attempts to understand and describe practice of strategy committees in the two-tier system of corporate governance. It also extends existing American experience on European perspective.

In summary, therefore, it may be concluded that the strategy committee is an expertise-related body of the board, of an advisory character to the supervisory board, which proposes solutions concerning company strategy, yet the final decisions are made by the entire board. The observed practices regarding the functioning of the strategy committee are in line with recommendations contained in Corporate Governance Code Russia (2014), which underline the importance of preliminary discussions on the company's strategic issues among the members of strategy committee, which put emphasis on preliminary discussions on key strategic issues for companies within the strategy committee. One important aspect of this committee's work is that its members have the possibility to explore problems to a greater depth, and that they cooperate with the management board. The quality of this latter aspect also determines the quality of the solutions proposed by the management board as regards the company strategy, and of the disclosed company information. The importance of this cooperation was also highlighted by A. Klein (1998), who emphasised e.g. the problem of asymmetry of information. This issue particularly gains in importance in the case of two-tier structure of governance, where the supervisory board and the management board are two separate bodies and their level of knowledge differ.

A strategy committee may be a standing body, or it may be appointed on an as-needed basis. In the second case, the strategy committee is dissolved following carrying out the designated task, which means that it is a temporary solution. This might explain, why there is no information concerning the strategy committee. Another factor that may condition the lack of more information about the strategy committee considers the fact, that its appointment is an internal good practice that companies do not have to report formally. The results of the research are convergent with J.R. Harrison's (1987) view that the number of committees might be actually higher. Furthermore they expand the list (suggested by this scientist) of possible explanations of this phenomenon to the aspect of the strategy committee's temporality. 
Apart from the need, the other factors that favour the formation of strategy committees is the size of the board and of the company itself. The more members in a board and the more complex the company's structure is, the greater is the likelihood of appointing a strategy committee. The key factor weighing in on the formation of a strategy committee is the need to formulate a new strategy, or to modify or update the existing one.

Not only experience and competences decide on membership in a strategy committee, but above all, the willingness to become involved in its works. The engagement of a strategy committee's member should result e.g. in taking the steps to gain knowledge about the company, to reduce the knowledge gap that exists between members of the management board (e.g. executive directors and members of the supervisory board (non-executive directors) (Klein, 1998).

Another significant factor, which decides on being a member of a strategy committee, is the need to distribute the committee workload equally among all members of the board. The intensity of the work of strategy committees is determined by the overall rhythm of works in connection with the preparation of a review of the company's strategy. The more "pressing" the issue of company strategy is, the higher is the committee's activity and the more frequent its meetings are.

The evaluation of the usefulness of strategy committees is rather positive. It was often perceived as a body through which the board is able to exert an influence on the shape of the company's strategy. It must however be remembered that the author of strategic plans is the management board, and the strategy committee should fulfil the role of their creative reviewer.

It is also worth bringing up once again that this research covered only supervisory board members with experience in strategy committees (10 out of 21 respondents). Without a doubt, both the number of interviewees and the perspective represented by them, that is limited exclusively to the supervisory board, is one of the restrictions of this research. In the future, it would be recommendable to find out more about the perception of strategy committees of other stakeholders in processes of strategic significance for companies. One group that could bring an interesting contribution in this respect are company CEOs and their management boards. It would be an interesting research challenge to explore how they evaluate the usefulness of strategy committees in the process of formation and modification of strategies. 


\section{REFERENCES}

Act on Statutory Auditors, Their Self-governing Organisation, Entities Authorised to Audit Financial Statements and on Public Oversight of May 7, 2009 (Journal of Laws of $2009 \mathrm{Nr}$ 77, item 649 with further amendments).

Cadbury Committee on the Financial Aspects of Corporate Governance (1992). The Report of the Committee on the Financial Aspects of Corporate Governance and Code of Best Practice, Gee Publishing.

Carpenter, M.A., \& Westphal, J.D. (2001). The Strategic Context of External Network Ties: Examining the Impact of Director Appointments on Board Involvement in Strategic Decision Making. Academy of Management Journal, 44(4), 639-660.

Casal, C. (2014). Building a Forward-looking Board. McKinsey Quarterly, 2, 119-126. Corporate Governance Code Russia (unofficial translation by EBRD) (2014). Retrieved from http://cbr.ru/Eng/sbrfr/files/Corporate_Governance_Code.pdf. Accessed January 11, 2017.

Dobija, D., Koładkiewicz, I., Cieślik, I., \& Klimczak, K. (2011). Komitety rad nadzorczych. Warszawa: Wolters Kluwer Polska Sp. z o.o.

Durisin, B., \& Puzone, F. (2009). Maturation of Corporate Governance Research, 1993-2007: An Assessment. Corporate Governance: An International Review, 17(3), 266-291.

European Commission (2005). Annex I to the EC Commission Recommendation of 15 February 2005 (2005/162/EC).

Fama, E.F., \& Jensen, M.C. (1983). Separation of Ownership and Control. The Journal of Law \& Economics, 26(2), 301-325.

Frey, H.H., \& Fontana, A. (2009). Wywiad. Od neutralności do politycznego zaangażowania, transl. M. Skowrońska. In: N.K. Denzin et al. (eds.), Metody badań jakościowych, vol. 2 (pp. 81-127). Warszawa: PWN.

Harrison, J.R. (1987). The Strategic Use of Corporate Board Committees. California Management Review, 30(1), 109-125.

Jeżak, J., \& Bohdanowicz, L. (2005). Struktura i formy sprawowania władzy w polskich spółkach akcyjnych w ocenie przewodniczących rad nadzorczych badanych spółek. In: J. Jeżak (ed.), Struktura i formy sprawowania władzy w spótkach akcyjnych. Łódź: Wydawnictwo Uniwersytetu Łódzkiego, p. $93-123$.

Kaczmarek, S., \& Nyuur, R. (2016). Review of the Literature on Board Committees: Taking Stock and Looking Ahead. International Journal of Business Governance and Ethics, 11(2), 89-115. 
Klein, A. (1998). Firm Performance and Board Committee Structure. The Journal of Law and Economics, 41(1), 275-304.

Koładkiewicz, I. (2014). Czynniki warunkujące skuteczność rad nadzorczych. Problemy Zarzadzania, 12, 2(46), 68-87.

Kvale, S. (2011). Prowadzenie wywiadów. Warszawa: PWN.

PwC (2015). Rady nadzorcze 2015. Trendy i kierunki zmian 2015.

PwC (2016). Rady nadzorcze 2016. Trendy i kierunki zmian 2016.

Pratt, M.G. (2009). From the Editors. For the Lack of a Boilerplate: Tips on Writing up (and Reviewing) Qualitative Research. Academy of Management Research, 5, 856-862.

Pyfel, Ł. (2015). Badacz jakościowy w świątyni liczb i pieniądza - wykorzystanie metod jakościowych w badaniu rynków finansowych. Przeglad Socjologii Jakościowej, 11(1), 70-83.

Silverman, D. (2009). Interpretacja danych jakościowych. Metody analizy rozmowy, tekstu i interakcji, transl. M. Głowacka Grajper, J. Ostrowska. Warszawa: PWN.

Spira, L.F., \& Bender, R. (2004). Compare and Contrast: Perspectives on Board Committees. Corporate Governance, 12(4), 489-499. 


\title{
PRAKTYKI DZIAKANIA KOMITETÓW STRATEGII W RADACH NADZORCZYCH
}

\begin{abstract}
Abstrakt
Tło badań. W artykule przedstawiono wyniki badania komitetów strategii w polskich radach nadzorczych. Badanie to jest pierwszym tego rodzaju badaniem europejskim prowadzonym w dwuszczeblowym systemie nadzoru korporacyjnego.

Cele badań. Celem badań było poznanie praktyki działania komitetów strategii w radzie nadzorczej, w tym określenie czynników warunkujących jego powołanie oraz kryteriów powołania jego członków, jego funkcji i zadań oraz sposobu działania tego komitetu.
\end{abstract}

Metodologia. Badanie zostało zrealizowane przy wykorzystaniu techniki wywiadu. W badaniu udział wzięło 10 celowo dobranych rozmówców, posiadających praktykę działania w radach nadzorczych spółek publicznych i osobiste doświadczenie w zakresie funkcjonowania komitetów strategii (jako ich członek lub członek rady nadzorczej, w której został on stworzony).

Kluczowe wnioski. Zgromadzone przez badanych członków rad doświadczenia wskazuja, że komitet strategii jest strukturalnym rozwiązaniem wspierajacym zaangażowanie rady $\mathrm{w}$ proces strategii. Ważnym wymiarem pracy tego komitetu jest możliwość lepszego poznania problemów o istotnym znaczeniu w procesie formułowania strategii. Komitet strategii może mieć charakter stały lub być tworzony ad hoc; czynnikami sprzyjającymi jego tworzeniu są wielkość rady oraz złożoność spółki.

Słowa kluczowe: komitet strategii, rada nadzorcza, strategia, nadzór korporacyjny, praktyka strategii 